NOTE

\title{
Seasonal associations between mid-tropospheric height patterns and precipitation in the western Great Basin, USA
}

\author{
Paul A. Knapp \\ Department of Geography, Georgia State University, Atlanta, Georgia 30303-3083, USA
}

\begin{abstract}
Associations between seasonal $700 \mathrm{mb}$ height data and precipitation data in the western Great Basin, USA, are examined from 1947 through 1991 using bivariate regression. Results show that approximately one-third of precipitation variability in the study region is associated with changes in $700 \mathrm{mb}$ heights during the autumn, winter, and spring months, but little associated variance occurs during summer. When only wet seasons are examined ( $Z$ scores $>0.5)$, correlations increase substantially. However, dry season ( $Z$ scores $<-0.5)$ data correlations had little interpretive value
\end{abstract}

KEY WORDS: Great Basin $700 \mathrm{mb} \cdot$ Precipitation · Acid environments

Seasonal precipitation fluctuations in arid environments often are a topic of concern because precipitation variability influences stream runoff, agricultural productivity, and municipal planning. In the western Great Basin, USA, moderate deviations from $30 \mathrm{yr}$ averages may cause severe flooding and dust storms, and they can adversely affect agriculture. Invariably, the consequences of either unusually wet or dry seasons heighten the discussion of what has caused the variability.

One way to understand certain aspects of precipitation variability is to look at associations between $700 \mathrm{mb}$ height data and precipitation. Studies have shown that $700 \mathrm{mb}$ height data are best for predicting precipitation in mid-latitude locations (Houghton 1969, Cayan \& Roads 1984, Klein \& Bloom 1987, Leathers 1991). In general (summer excluded), $700 \mathrm{mb}$ heights are correlated negatively with precipitation amounts, but this relationship is affected by the placement of ridges and troughs associated with meridional flow (Harman 1991). Areas under ridges are typically associated with dry conditions (e.g. Namias 1978), while areas affected by troughing may experience either wet or dry conditions depending on the exact placement of the trough axis (e.g. Yarnal \& Leathers 1988). Variability in the latter case arises because the east side of the mean trough is a zone of frequent positive vorticity advection that favors precipitation, while the west side of the trough is a zone of frequent negative vorticity advection that suppresses precipitation events (Harman 1991).

The objective of this paper is to examine seasonal associations between mid-tropospheric pressure heights and precipitation in the western Great Basin for a $45 \mathrm{yr}$ period (1947 to 1991). Because interannual precipitation variability prevails within the study area, synoptic controls influencing wet and dry seasons are analyzed.

Study area. The study sites lie within the western Great Basin, an area of approximately $390000 \mathrm{~km}^{2}$ comprising southeastern Oregon, extreme eastern California, northern and central Nevada, southern Idaho, and western Utah (Fig 1). The Great Basin is a high, mid-latitude desert interspersed with hundreds of north-south oriented fault-block mountains separated by broad, flat basins. Mean annual temperatures at the sites average approximately $9^{\circ} \mathrm{C}$ with both large annual and diurnal ranges. Annual precipitation averages $20 \mathrm{~cm}$. Percentages of annual precipitation occurring during winter, spring, summer, and autumn are $31,29,17$, and 23 , respectively

Data and methods. Precipitation data from December 1946 through November 1991 were used. The study group consisted of 9 stations, 7 from Nevada and 2 from Oregon (Fig. 1). All stations were between 1208 and $1712 \mathrm{~m}$ in elevation. The original potential data set contained all stations that fell within the western Great Basin - all areas west of the $115^{\circ} \mathrm{W}$ boundary. This boundary delineation was made because the $115^{\circ}$ meridian is the dividing line between frequent and infrequent summertime invasions of Gulf of Mexico air 


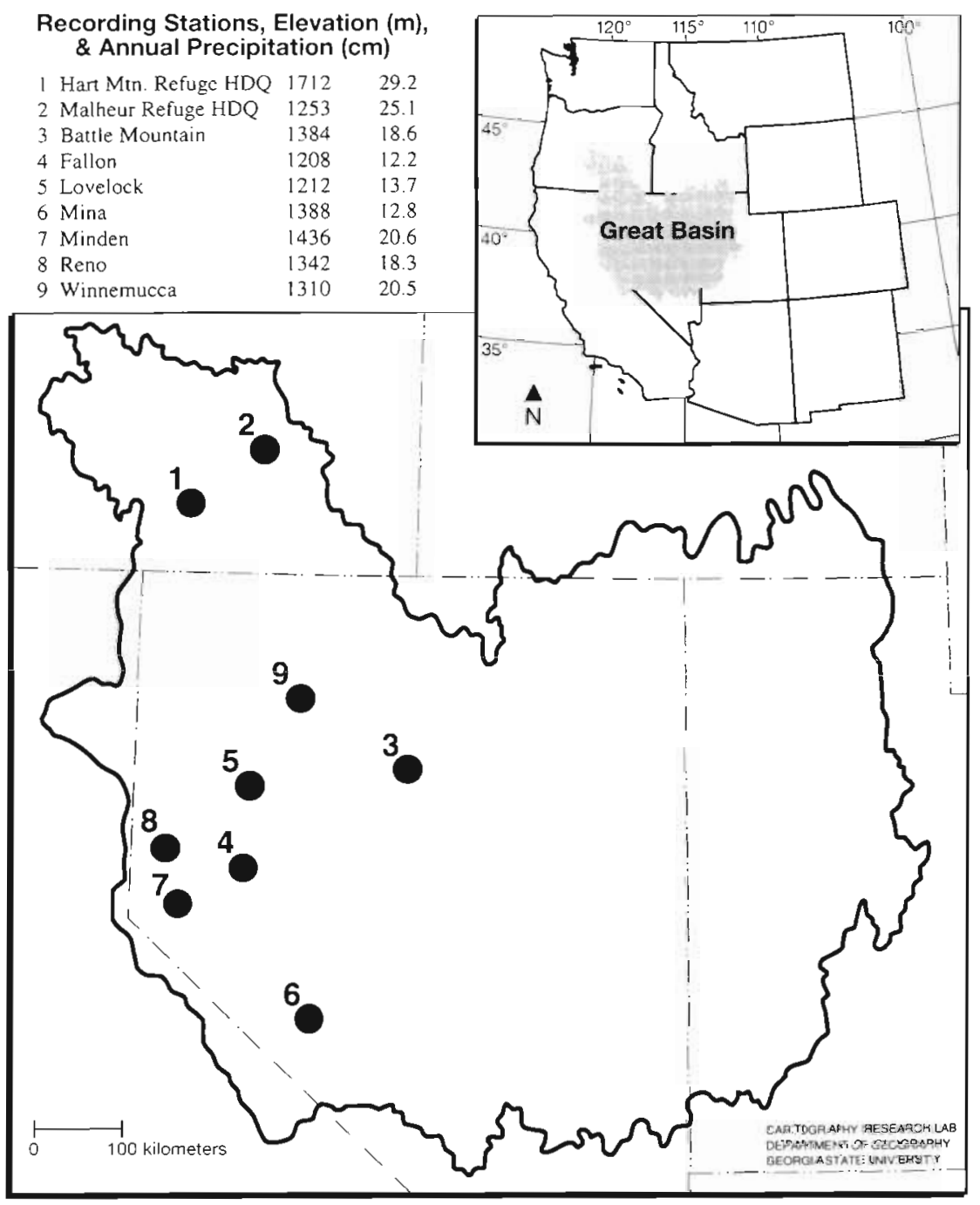

Fig. 1 Location of Great Basin study sites, USA

masses that are responsible for convective rain showers (Houghton 1969). The 9 stations were chosen because of their length of record (beginning no later than December 1946) and their completeness. The precipitation data were provided by the Western Regional Climate Center and were organized as monthly values by station. Standard seasonal definitions were used (i.e. winter $=$ December, January, February) to calculate seasonal averages.

Gridded seasonal $700 \mathrm{mb}$ height data were provided by the Scripps Institution of Oceanography. Seasonal height data intersecting at 4 grid points, $40^{\circ} \mathrm{N}$ at $100^{\circ}$, $110^{\circ}, 120^{\circ}$, and $130^{\circ} \mathrm{W}$, were used from 1947 through 1991. The grid points intersecting at $100^{\circ}, 110^{\circ}$, and $130^{\circ} \mathrm{W}$ were not used in any direct association with data from the surface recordings, but rather were included to get a greater spatial perspective of temporal changes in the $700 \mathrm{mb}$ height data. Seasons were the same as for the precipitation data.
Data analyses (SAS 1985) involved bivariate regression of aggregate seasonal precipitation data with $700 \mathrm{mb}$ height data using the height data as the independent variable. Mean seasonal precipitation values were standardized around a mean of 0 and a standard deviation of 1 to produce a set of $Z$ scores. Three sets of regression analysis were run: first, all seasonal precipitation data were included; second, only seasonal precipitation values with $Z$ score values of $>0.5$ (indicating wet seasons) were analyzed; and finally, only seasonal precipitation values with $Z$ scores $<-0.5$ (dry seasons) were used. Cook's $D$ and studentized residual values were used as diagnostic tools to check for possible statistical distortions (i.e. outliers and influential observations) associated with bivariate regression (SAS 1985, Clark \& Hosking 1986).

Results and discussion. Regression analyses used to predict seasonal precipitation as a function of $700 \mathrm{mb}$ height were significant for all seasons (Table 1). For the 
Table 1 Results of regression analyses predicting seasonal precipitation as a function of seasonal $700 \mathrm{mb}$ height data in the western Great Basin, USA. Coefficient of determination $\left(\mathrm{r}^{2}\right)$ is show $\mathrm{n}$ on top, while corresponding $F$ value is shown in parentheses

\begin{tabular}{|c|c|c|c|c|}
\hline & Winter & Spring & Summer & Autumn \\
\hline Complete record & $\begin{array}{c}0.25 \\
(14.04)^{*}\end{array}$ & $\begin{array}{c}0.33 \\
(20.83)\end{array}$ & $\begin{array}{c}010 \\
(4.65)^{\circ}\end{array}$ & $\begin{array}{c}0.39 \\
(28.01)^{\circ}\end{array}$ \\
\hline$Z$ score $>0.5$ & $\begin{array}{c}0.57 \\
(14.85)^{*}\end{array}$ & $\begin{array}{c}0.37 \\
(7.22)^{\circ}\end{array}$ & $\begin{array}{c}0.16 \\
(2.28)\end{array}$ & $\begin{array}{c}0.48 \\
(5.61)^{\circ}\end{array}$ \\
\hline$Z$ score $<0.5$ & $\begin{array}{c}0.04 \\
(0.56)\end{array}$ & $\begin{array}{c}0.10 \\
(1.72)\end{array}$ & $\begin{array}{c}0.08 \\
(1.60)\end{array}$ & $\begin{array}{c}0.14 \\
(2.30)\end{array}$ \\
\hline
\end{tabular}

complete record, the strongest associations occurred during autumn. Models for spring and winter provided less associated variance, and the weakest relationships were during the summer. When only wet seasons were included, the amount of associated variance increased during all seasons (Table 1), but the summer model was insignificant at the 0.05 level. Analyses of dry season data showed no significant $r^{2}$ values and all values were below that for the complete record.

Moisture for precipitation within the Great Basin comes from 2 regions: a flow from the Pacific Ocean providing moisture principally from October through April and an influx of warm, moist air streaming in from the Gulf of Mexico from mid to late summer Precipitation events are associated with 3 flows (Houghton 1969, Houghton et al. 1975). First, low pressure systems from the Pacific Ocean during winter produce the major precipitation events. These events are affected greatly by orographic features. The influence of this orographic lifting is most important in the western Great Basin where the Sierra Nevada creates a major rain shadow on its lee side. Second, cyclogenesis on the lee side of the Sierra Nevada mountains creates Great Basin lows and these lows cause precipitation from late fall through spring. Lee-side lows are most common in late spring. Third, during summer, a midcontinental high over the Mississippi Valley will often shift westward towards the Four Corners region (i.e. Arizona, Colorado, New Mexico, and Utah). The anticyclonic flow around this high feeds moisture from the Gulf of Mexico providing sufficient conditions for convective showers; however, this summertime source is most important east of the $115^{\circ} \mathrm{W}$ meridian.

Results of the regression analyses showed that wet winters were correlated better with $700 \mathrm{mb}$ heights than either the complete record or dry $(Z<-0.5)$ winters. Wet winters in the western Great Basin are caused most commonly by the presence of a well- developed low centered off the Pacific Coast. Concurrent mid-tropospheric flow is meridional, with southwesterly flow aloft bringing moisture inland. Upperlevel lows of the Pacific Coast may remain anchored for several weeks, where a series of fronts triggered by traveling shortwaves can produce large precipitation totals (Houghton 1969). While the above conditions are most common, brief, wet conditions in the western Great Basin can occur during what is otherwise a winter characterized by high $700 \mathrm{mb}$ heights. During February 1986, for example, almost all the annual average of precipitation fell during a 1 wk period. These rare events serve to complicate the association between lower $700 \mathrm{mb}$ heights and increased precipitation.

Dry winters can be associated with both high pressure (e.g. in 1977 when the second lowest amount of precipitation and the second highest $700 \mathrm{mb}$ pressure occurred during the study period) and low pressure (e.g. in 1966 when the sixth driest winter and third lowest winter $700 \mathrm{mb}$ heights occurred during the study period). In situations such as the latter, the position of the upper-level trough may be centered in the eastern Great Basin over Utah or even further east. As a result, air flow into the western Great Basin is northwesterly (with slight subsidence) and provides little precipitation as fronts pass the Sierra Nevada crest.

Higher associated variance also occurred during spring and autumn during wet $(Z>0.5)$ seasons than for either the complete record or dry seasons. The greater amount of associated variance during wetter years is likely the result of the same causes as for wet winters. In addition, Great Basin lows (i.e. upper- level, cut-off lows) form on the lee side of the Sierra Nevada. These closed lows, depending on their location, can produce upslope conditions (and great precipitation) and may persist for several days or longer (Houghton 1969), providing another cause of simultaneous low $700 \mathrm{mb}$ height data and precipitation accumulation. Lower associated variance during dry spring and autumn seasons was caused by the same reasons as for winter, but with the additional confounding influences of the Great Basin lows. The most common position of the axis of these Great Basin lows is centered east of the recording stations (eastern Nevada and western Utah). Hence, as with the Pacific fronts, if the recording stations are slightly upstream of the low pressure core, the stations remain dry while simultaneously being located under lower $700 \mathrm{mb}$ heights.

Low $\mathrm{r}^{2}$ values in the summer were not surprising. Summertime precipitation is a function of small-scale convectional uplift and is associated poorly with midtropospheric flow. Rainfall accumulations are spotty with this type of activity, so it is not unusual for one area to receive $0.5 \mathrm{~cm}$ or more precipitation from a storm while an area nearby remains dry. The likeli- 
hood of precipitation also increases in the Great Basin when high pressure and anticyclonic flow are centered slightly east of the Basin, and/or low pressure with accompanying cyclonic flow (often associated with tropical depressions) lie westward. Either individually or in concert, the result is an influx of moisture into the Basin that, when coupled with atmospheric instability, triggers showers, but is associated weakly with midtropospheric patterns.

Conclusions. Results indicate that approximately one-third of the total precipitation variance can be explained by variations in the mid-tropospheric heights during autumn, winter, and spring, but substantially less during summer when looking at the complete record. These values are in rough agreement with previous, similar studies (e.g. Leathers 1991, Leathers et al. 1991). When wet seasons are examined, however, associated variance increases substantially, particularly during the winter and autumn seasons, and somewhat less during the spring. Conversely, examination of dry seasons indicates that associated variance is less in comparison to the complete record. These results suggest several key points. First, wet seasons are usually associated most strongly with upper-level lows centered offshore if circulation around the low causes a southwesterly (and moist) flow into the western Great Basin. Second, dry seasons may be caused either by the dominance of high pressure, if centered over the western Great Basin, or by the persistence of low pressure, if the axis of the upper-level low is centered east of the recording stations. In conclusion, wet seasons are most often associated with 1 cause: lower $700 \mathrm{mb}$ heights. Few wet years are characterized by a dominance of high pressure, hence the high degree of associated variance. Conversely, at least 2 causes for dry seasons exist: the dominance of either high or low $700 \mathrm{mb}$ heights; therefore, bivariate regressions reveal little associated variance.

Editor: V. Meentemeyer, Athens, Georgia, USA
Acknowledgements. I thank Peter Soule, Henri GrissinoMayer, Kelly Redmond, and 2 anonymous reviewers for their constructively critical comments, Jeffery McMichael for cartographic work, and Catherine McGovern for editorial assistance. The $700 \mathrm{mb}$ height and precipitation data were kindly provided by the Scripps Institution of Oceanography and the Western Regional Climate Center, respectively.

\section{LITERATURE CITED}

Cayan, D. R., Roads, J. O. (1984). Local relationships between United States west coast precipitation and monthly mean circulation parameters. Mon. Weather Rev. 112: $1276-1282$

Clark, W. A. V., Hosking, P. L. (1986). Statistical methods for geographers. John Wiley and Sons, New York

Harman, J. R. (1991). Synoptic climatology of the westerlies: processes and patterns. Association of American Geographers, Washington, DC

Houghton, J. G. (1969). Characteristics of rainfall in the Great Basin. Desert Research Institute, Reno, NV

Houghton, J. G., Sakamoto, C. M., Gifford, R. O. (1975). Nevada's weather and climate. Nevada Bureau of Mines and Geology, Reno

Klein, W. H., Bloom, H. J. (1987). Specification of monthly precipitation over the United States from the surrounding $700 \mathrm{mb}$ height field. Mon. Weather Rev. 115: $2118-2132$

Leathers, D. J. (1991). Relationships between $700 \mathrm{mb}$ circulation variations and Great Plains Climate. Great Plains Res. 1: $58-76$

Leathers, D. J., Yarnal, B., Palecki, M. A. (1991). The Pacific/ North American teleconnection pattern and United States climate. Part I: Regional temperature and precipitation patterns. J. Clim. 4: 517-528

Namias, J. (1978). Multiple causes of the North American abnormal winter 1976-1977 Mon. Weather Rev. 106: $279-295$

SAS (1985). SAS user's guide: statistics, Version 5 edn. SAS Institute, Inc., Cary, NC

Yarnal, B., Leathers, D. J. (1988). Relationships between interdecadal and interannual climatic variations and their effect on Pennsylvania climate. Ann. Ass. Am. Geogr. 78: $624-641$

Manuscript first received: June 3,1993

Revised version accepted: February 28, 1994 